\title{
An analysis of inclusion gaps in sustainable development themes: Findings from a review of recent social work literature
}

\section{Introduction}

Humans have negatively altered global ecosystems more rapidly and more dramatically over the last 50 years than in any comparable time period (World Wildlife Fund (WWF), 2014, 2016). Humans cannot survive without a healthy planet. Earth's ecosystems and the services they provide allow for human life through the provision of clean air and water, food, medicines, disease management, building materials, fuel, climate regulation, storm buffering, security and shelter, spiritual fulfillment, and more. Yet, humanity's current natural resource consumption and carbon emissions combined exceed Earth's (land and sea) production and carbon absorption capacity by 50\% (WWF, 2014), meaning Earth will be unable to sustain the burgeoning human population without intervention. These unsustainable demands have led to substantial gains in wellbeing and economic development for some, but at the cost of health, wellbeing, and security for most humans, particularly already marginalised and oppressed populations, making this a pressing social work concern. However, many social work professionals have not been exposed to the prevalence and severity of these environmental issues and the direct negative impacts on their clients, policies, and interventions. 
Scientists have long known that excessively taxing Earth's natural resources and processes could lead to devastating consequences, including abrupt and irreparable environmental change (Meadows et al., 1972). In an effort to define parameters within which humans can develop sustainable societies, contemporary scientists have suggested nine planetary boundaries, or guidelines, for utilising each Earth system that minimises the risk of causing irreversible changes (Rockstrom et al., 2009; Steffen et al., 2015). These systems include climate change, biodiversity loss, nitrogen and phosphorus use, freshwater use, land use change, ocean acidification, stratospheric ozone depletion, atmospheric aerosol pollution, and chemical pollution; three boundaries that we have already violated are climate change, biodiversity loss, and nitrogen cycle disruption (Rockstrom et al., 2009; Steffen et al., 2015). Rather than strict tipping points that would flip a physical system into an alternate state, these boundaries are based on an evolving understanding of Earth's functioning and resilience; as such, they exist on a risk continuum where the farther these boundaries are transgressed, the higher the risk humans run of destabilising Earth's processes and eroding both human and Earth's resilience (Steffen et al., 2015). While Earth could rebound from such destabilisation, the resulting changes to Earth's environment would be so drastically different that human life likely could not (Steffen et al., 2015). 
Environmental changes are so pervasive and severe that scientists have suggested humans are already causing the Earth to exit the current geological epoch, the Holocene, which has existed for over 10,000 years and made the development of human civilisations possible, into the Anthropocene, a term under review by the International Commission on Stratigraphy to become a formal geological time period (Lewis and Maslin, 2015; Steffen et al., 2007; Steffen et al., 2011). The Anthropocene is defined as a period when human activity has overtaken vast parts of Earth's natural cycles, and in ways that threaten humanity's future (Lewis and Maslin, 2015).

The period 1800-1850 marks industrialisation's and the Anthropocene epoch's approximate onset, as industrial societies rapidly expanded their fossil fuel use (Steffen et al., 2007). Fossil fuels provided humans with abundant energy for developing new technologies (e.g., steam engines), eliminating previous energy supply constraints and altering and intensifying resource use for medicine and agriculture. Consequently, between 1800 and 2000, energy use grew approximately 40-fold, the global economy approximately 50-fold, and human population more than six-fold (Steffen et al., 2007). Since World War II, human population has continued to grow almost exponentially, doubling in 50 years, reaching more than 6 billion at the end of the $20^{\text {th }}$ century, and increasing to 7.6 billion as of this writing, with the last billion added in just the past 12 years (United Nations, World 
Population Prospects, 2017). Human activity has also rapidly increased, with the number of motor vehicles jumping from 40 million in 1945 to 700 million in 1996 and petroleum consumption growing 3.5 times since 1960 (Steffen et al., 2007). This alarming growth in population and consumption was occurring concurrently with early scientific recognition and documentation of the extent that human activities were affecting Earth's functioning (Steffen et al., 2007; Steffen et al., 2011).

Impacts of climate change, including rising temperatures, shifting seasons, sea-level rise, and increasing droughts and floods, threaten people's abilities to meet basic needs (Raworth, 2012). Already, 1,000 children die daily from climate change-related starvation and disease (Salomon, 2016). Furthermore, rising carbon dioxide levels contribute to the acceleration of environmental change and weather anomalies (Raworth, 2012). Experiencing extreme weather events not only poses serious physical threats, but can also have severe psychological consequences by increasing individuals' overall stress, making increases in substance abuse, anxiety, depression, and suicide more likely (Clayton et al., 2014). Severe disasters like floods and storms can also have damaging effects on individuals, families, and communities by making people susceptible to post-traumatic stress disorder, significantly affecting children's learning and development, and even increasing physical aggression within the home (Clayton et al., 2014). 
Excessive human consumption has depleted biodiversity levels below a safe threshold (Newbold et al., 2016), violating another planetary boundary and causing the $6^{\text {th }}$ mass extinction (Ceballos et al., 2015). Biodiversity loss has become so severe - occurring at a rate at least 114 times what is natural (Ceballos et al., 2015) - that the current extinction rate is comparable to the last global mass-extinction event, commonly remembered as the dinosaurs' extinction (Sodhi and Ehrlich, 2010). Specifically, between 1970 and 2010, the number of individual animals decreased by 52\% (WWF, 2014). During the same time period, freshwater species declined $76 \%$, followed by marine and terrestrial species each declining at 39\% (WWF, 2014). The current loss rate is unsustainable, and depleting ecosystem resilience threatens human security and creates deleterious economic repercussions (Rockstrom et al., 2009). For example, 15\% of animal protein in human diets comes from marine ecosystems and fisheries support 660 million jobs globally; without abating threats to oceans, predicted economic losses are $\$ 428$ billion by 2050 (WWF, 2014). Another ecosystem service humans need for survival is bee pollination. Bees are the most economically important pollinator in the world, as the value of U.S. crops pollinated by bees in 2009 was estimated at $\$ 15.2$ billion (Calderone, 2012). Globally, bees pollinate 71 of the 100 crops that provide $90 \%$ of the world's food (UNEP, 2010). 
In 2003, Mascia et al., put out a call to action to all social sciences to collaborate with natural sciences in conservation initiatives, for Earth and humanity's preservation. As a practice-based profession with adept skills in advocating for human health and well-being and organising and empowering communities, no social science profession is better poised to help protect a future for humanity than social work.

\section{Methods}

We performed a comprehensive review of recent social work literature (published 2010-2015) to uncover existing gaps in sustainable development themes relevant for social work practice. The review was completed according to a fixed and systematic plan established a priori and based on the Campbell Collaboration Resource Center methodology and in consultation with a university research librarian. Databases, explored one-by-one, were: Social Services Abstracts, PsycINFO, Social Sciences Citation Index (Web of Science), Sociological Abstracts, Academic Search Complete, ProQuest Central, EBSCOhost, Dissertations and Theses, and Google Scholar. Peer-reviewed articles (including editorials), social work reports, white papers, and dissertations and theses about the theories and practice of sustainable development-related work in social work practice and research in English were examined. Keywords used were social work research, social work, sustainable development, natural environment, environmental sustainability, green 
social work, environmental social work, conservation social work and indigenous social work.

The search terms were grouped into 10 categories: social work research AND sustainable development; social work research AND natural environment; social work research AND environmental sustainability; social work AND sustainable development; social work AND natural environment; social work AND environmental sustainability; green social work; environmental social work; conservation social work; and indigenous social work AND sustainable development. For each search yield, titles and highlighted search terms were first read to ascertain possible relevance. For pertinent titles and search terms and those that were published in a social work or social welfare journal, abstracts were read for appropriateness to our search. Most of the 1690 articles yielded were found to be irrelevant after abstract review; for example, "sustainable development" often meant sustainable development of an organisation (e.g., economically, human resources, ethically). Our criteria were that works needed to a) integrate human needs for the natural environment or needs for the natural environment's protection into social work research, or b) recognise the natural environment's importance to human health and development. Works regarding nature's therapeutic benefits and/or of animals were not included as those were not germane to our concerns. However, if for example, a community organic garden 
effort was conducted or evaluated by a social work or social welfare practitioner/researcher and found to also have mental health benefits to the community, those works were included. This same process was utilized for each separate database, and relevant articles were recorded in a research notebook by the first author and later reviewed by the second author. The first and second author conducted the review independently. To address interrater reliability, the second author's findings were compared to the first author's, which resulted in the inclusion of an additional 11 papers; the first and second authors reached aggregate consensus.

The general database search yielded 60 relevant publications. We further investigated the references cited in the original 60 papers for additional citations not covered in the database search. We elected to include this step out of concern that refereed journals requiring keyword selection from a pre-existing keyword database may not yet have keywords congruent with environmental social work, thus hindering indexing which would have influenced the search criteria's yield. This method produced an additional 11 relevant publications that were not included in the original search, yet highly relevant to the literature review. These 11 publications were included in the screened-in publications. After completing all steps of the review, 71 papers were included in the analysis. The full 
list of screened-in peer-reviewed manuscripts (including editorials), dissertations, theses, and white papers can be found in Appendix 1.

Study quality was not assessed, as that was not the review's intent. The objective was to analyse social work research to gain an understanding of if and how social work researchers were thinking about and/or addressing sustainable development. Study characterisation denoted eight categories: empirical, theoretical, pedagogical application, literature review, editorial/call to action, white paper, thesis, and dissertation.

\section{Results}

As a quantitative framework, 2,014,451 (ProQuest) social work publications were produced from 2010 through 2015. Our review screened-in 71 applicable publications, representing $0.00004 \%$ of social work research published from 2010-2015. Of these, 17 (24\%) works were dissertations/theses and white papers and $54(76 \%)$ were published in peer-reviewed journals (including editorials). Combined, special issues of International Journal of Social Welfare in 2012, and Australian Social Work in 2013 produced 18 $(33.3 \%)$ of the screened-in peer-reviewed articles. Four journals published 29 of the 54 (53.7\%) articles: International Journal of Social Welfare, Australian Social Work, Social Work Education and Social Work Research. Scholars J. H. Williams, J. Drolet, J. McKinnon, C.A. Faver, J. L. Willett, M. Gray, and J. Coates authored 19 (26.8\%) of the 
total products and $18(33.3 \%)$ of the peer-reviewed articles. Table 1 presents screened-in publication findings characterisation.

\section{<Insert Table 1 here>}

Empirical studies most frequently used qualitative methodologies $(n=8(44.5 \%))$, followed by quantitative and community-based participatory action research methodologies that were equally represented with four $(22.2 \%)$ articles each. Mixed-methods research was used in two (11.1\%) articles. Only one product (Walke, 2015) included intervention research. Of the 18 theoretical articles published in peer-reviewed journals, six $(33.3 \%)$ were specific to social work education. The three products classified as pedagogical application differed from these six articles, as they moved beyond conceptual modeling to present case studies evaluating specific teaching techniques or curriculum content previously used in a classroom setting.

We also analysed trends over the five-year period. Figure 1 demonstrates that journal publications are on the rise, while dissertations, theses and white papers show a steady upward trend.

\section{$<$ Insert Figure 1 here $>$}

It is important to note that at least two significant social work texts within this theme were produced during the time frame investigated: Lena Dominelli's Green social 
work: From environmental crisis to environmental justice (2012) and Mel Gray, John Coates, and Tiani Hetherington's Environmental Social Work (2012).

\section{Discussion}

Earth's continued sustainability for humans can no longer be taken for granted (Millennium Ecosystem Assessment, 2005; Rockstrom et al., 2009; Steffen et al., 2015). Environmental changes due to unchecked human population growth and overconsumption now threaten human survival, with the poorest and most vulnerable on Earth impacted most significantly despite causing the least damage themselves (Raworth, 2012), making this a pressing social justice issue facing social work practitioners (Tedeschi et al., 2013).

While the review was limited by the inclusion of only English papers, findings led to the conclusion that recent social work research and academic literature do not adequately account for environmental degradation and sustainability issues, even when they are directly linked to human and social development. Despite evidence that many environmental problems are intrinsically linked with social justice issues aligned with social work's mission (e.g., food security, protecting environmentally induced migrants, or environmental racism) (Dominelli, 2012; Schmitz et al., 2012), the lack of intervention studies in the review's findings indicate social work is failing to make a substantial contribution to mitigating environmental degradation's growing threat to human health, 
well-being, and survival. The finding that environmental degradation and sustainability account for less than $1 \%$ of all social work research suggests that these issues and themes are not prioritised. If the products from the two special issues are removed from the data count, 36 peer-reviewed publications in a six-year time span remain. Publication biases, funding barriers, institutionally perpetuated disciplinary boundaries, and low value attributed to interdisciplinary research in tenure systems have been cited as impediments to interdisciplinary environmental research by both natural and social scientists (Roy et al., 2013), and have also likely hindered prioritisation of these themes in social work research and influenced these findings.

In a 2013 survey, $83 \%$ of 179 natural and social scientists conducting research at the human-environment interface reported frequent or occasional trouble publishing manuscripts since the interdisciplinary research did not adhere to preferred methodological and theoretical approaches or traditional journal guidelines, frameworks, and interests, which were often perceived as disciplinary (Roy et al., 2013). Though influenced by the presence of two special issues, the finding that more than $50 \%$ of screened-in peerreviewed articles were published in only four journals may be evidence of a publishing bias or challenge in regards to human-environment research rooted in social work. As such, the low number of empirical studies (18 in six years), may also be representative of a 
publishing bias, and not an accurate reflection of the amount of environmental research conducted by social workers.

The documented schism between "evidence-based practice" and "practice-based research" in social work (Anastas, 2015) is also a reminder that the lack of environmental social work research may not be reflective of the extent that sustainable development and environmental degradation themes are incorporated into practice and unpublished or unevaluated interventions. Indeed, globally numerous social service organisations and grass roots organisations employing social work strategies are working at the interface of environmental challenges and social injustices and thus impacting both social and sustainable development (e.g., India’s Navdanya, Kenya's Green Belt Movement, Cambodia's 3S Rivers Protection Network). While they may not disseminate their work through traditional academic (e.g., peer-reviewed literature) and development (e.g. white papers and technical reports) channels, these organisations present potential opportunities for collaborations with social work researchers who have the abilities to amplify these organisations' voices by assisting in the dissemination of their findings to newer and broader audiences.

Approximately $20 \%$ of all screened-in products, and $25 \%$ of peer-reviewed products specifically, are editorials or calls to action. While these articles often cite clear and cogent 
evidence of the changing environment's effects on, and relevance to, social work practice, and explicitly link social work to the environmental sciences, the evidence suggests that they are not being heeded. Several factors are likely perpetuating this inaction. Social workers are not the only population difficult to motivate in regards to environmental action. The enormity of problems and challenges often creates a paralysis or apathy that leads to inaction (Clayton et al., 2014; Moser, 2007), which in research and academia, is likely exacerbated by the aforementioned institutional barriers, publication biases, and other challenges to interdisciplinary research. This paralysis and apathy could be further complicated in social work, a profession that is already frequently overtaxed, and whose breadth of social injustices pertinent to its mission is continually expanding.

Regardless of root causes, these persistent gaps remain problematic. Without using research to explore the intricate links between environmental degradation and social justice, the social work profession will fail to build an evidence-base grounded in the profession's values or to inform practice with the marginalised and vulnerable communities social workers serve, who will be impacted most severely by environmental change. These literature gaps will also continue to perpetuate knowledge gaps in social work curricula and practice, creating a reliance on other disciplines to create the knowledge base that will be needed for future social work practitioners (Brekke, 2012). It can be said with certainty that 
global environmental problems are exponentially worsening (Steffen et al., 2015), and that social workers will be unable to ignore these problems when utilising complex systems approaches in their practice. Therefore, the evidence-based knowledge they will seek to inform their advocacy and interventions with clients should be rooted in social work values and derived from the social work profession itself.

Because environmental change shares a complex association with social justice, other professions will potentially begin to implement traditionally social work services and interventions, without the unique social work training that is rooted in cultural competence toward marginalised and oppressed populations. Proctor (2010), offers historical cautionary tales about specific social work sectors (e.g., case management and disaster response) where other professions usurped social work "turf" due to a lacking social work research presence. The results included diminished credibility to the social work profession, its training, proffered services, and outcomes as well as undue risk to vulnerable populations.

The review also yielded positive findings in contemplating how the field moves forward and further engages in environmental and sustainability challenges. First, differing methodological approaches are cited as a barrier to interdisciplinary environmental research (Roy et al., 2013). Though only 18 empirical journal articles were included in this review's final data set, they represented a breadth of research methodologies. Qualitative methods 
were the most frequently cited approach, despite the natural and environmental sciences' reliance on quantitative frameworks (Roy et al., 2013), demonstrating that some barriers are penetrable. The 18 theoretical journal articles also synthesised diverse theories, integrating traditional social work theories with ecological and environmental theories to form robust interdisciplinary conceptual models. While still limited in number, these conceptual and theoretical models should provide the foundations for intervention studies and further empirical research.

Though J.H. Williams, J. Drolet, J. McKinnon, C. A. Faver, J. L. Willet, M. Gray, and J. Coates authored $33 \%$ of the peer-reviewed articles, their credentials range from a Dean Emeritus (J. H. Williams), to the author of a doctoral dissertation completed in 2015 (J. L. Willett). Student theses and dissertations account for $18.3 \%$ of all screened in products, suggesting that the next generation of social work scholars are interested in moving the field forward, and integrating these concepts into their own scholarship. To continue this progress, social work faculty who serve as mentors and advisors need to support these students with receptivity to their pioneering ideas and a willingness to embrace an interdisciplinary approach to mentorship. Building collaborative teams within the field, and across disciplines, is essential. 
Social work researchers interested in the human-environment interface also appear to be making progress within the field of social work as the American Academy of Social Work \& Social Welfare (AASWSW) acknowledged the field's response to global environmental change as one of the 12 grand challenges for social work (AASWSW, 2016; Kemp and Palinkas, 2015). Raising awareness and recognition of the linkages is not enough, though. Future calls to action and theoretical frameworks need to be more effective at stimulating empirical research, and one strategy may be to include specific future directions for research, as well as resources and strategies for overcoming previously noted interdisciplinary research barriers. Global environmental change is the most dangerous crisis facing humanity, and it is critical that much needed social work practitioners are prepared and equipped to intervene in environmental challenges and that social work researchers have clear paths to disseminate their interdisciplinary research. There is also an urgent need for social work intervention research to stimulate change at the macro, mezzo, and micro levels through behaviour change, policy, and advocacy — ensuring a sustainable and equitable usage of Earth's resources.

Global environmental change is a grand challenge for all professions, including social work, in the $21^{\text {st }}$ century. Ultimately the findings of this review demonstrate the need for greater recognition of this challenge in social work research. 


\section{Disclosure of Conflict Interests}

The authors have no conflict interests to disclose. 


\section{References}

American Academy of Social Work \& Social Welfare (AASWSW) (2016). 'Grand Challenges for Social Work'. Available online at: http://www.aaswsw.org/grandchallenges-initiative/

Anastas, J. (2015) 'Clinical Social Work, Science, and Doctoral Education: Schisms or Synergy?', Clinical Social Work 43(3): 304-312.

Brekke, J. (2012) 'Shaping a Science of Social Work', Research on Social Work Practice 22(5): 455-464.

Calderone, N.W. (2012) 'Insect Pollinated Crops, Insect Pollinators and US Agriculture: Trend Analysis of Aggregate Data for the Period 1992-2009', PLoS ONE 7(5): e37235.

Ceballos, G., P.R. Ehrlich, A.D. Barnosky, A. Garcia, R.M. Pringle and T.M. Palmers (2015) 'Accelerated Modern Human-Induced Species Losses: Entering the Sixth Mass Extinction', Science Advances 1(5): e1400253. 
Clayton, S., C.M. Manning and C. Hodge (2014) Beyond Storms and Droughts: The Psychological Impacts of Climate Change. Washington, D.C.: American Psychological Association and ecoAmerica.

Dominelli, L. (2012) Green Social Work: From Environmental Crisis to Environmental Justice. Hoboken, NJ: Wiley.

Gray, M., J. Coates, J. and T. Hetherington (eds) (2012) Environmental Social Work. New York, NY: Routledge Publishing.

Kemp, S. P., and L.A. Palinkas (2015) Strengthening the Social Response to the Human Impacts of Environmental Change. Baltimore, MD: AASSW.

Lewis, S.L. and M.A. Maslin (2015) 'Defining the Anthropocene', Science 519(7542): 171180.

Mascia, M. B., J.P. Brosius, T.A. Dobson, B.C. Forbes, L. Horowitz, M.A. McKean and N.J. Turner (2003) 'Conservation and the Social Sciences', Conservation Biology 17(3): 649-650.

Meadows, D.H., D.L. Meadows, J. Randers and W.R. Behrens (1972) The Limits to Growth. New York, NY: Universe Books.

Moser, S. C. (2007) 'More Bad News: The Risk of Neglecting Emotional Responses to Climate Change Information', in S.C. Moser and L. Dilling (eds) Creating a 
Climate for Change: Communicating Climate Change and Facilitating Social Change. Cambridge, UK: Cambridge University Press, pp. 64-80.

Millennium Ecosystem Assessment (2005) Ecosystems and Human Well-Being:

Biodiversity Synthesis. Washington, D.C.: World Resources Institute.

Newbold, T. L.N. Hudson, A.P. Arnell, S. Contu, A. De Palma, S. Ferrier, S.L.L. Hill, A.J. Hoskins, I. Lysenko, H.R.P. Phillips, V.J. Burton, C.W.T. Chng, S. Emerson, D. Gao, G. Pask-Hale, J. Hutton, M. Jung, K. Sanchez-Ortiz, B.I. Simmons, S. Whitmee, H. Zhang, J.P.W. Scharlemann and A. Purvis (2016) 'Has Land Use Pushed Terrestrial Biodiversity Beyond the Planetary Boundary? A Global Assessment', Science 353(6296): 288-291.

Proctor, E. (2010) 'The Question of Questions: An Agenda for Social Work Practice Research', in A. E. Fortune, P. McCallion and K. Briar-Lawson (eds) Social Work Practice Research for the Twenty-First Century. New York, NY: Columbia University Press, pp. 253-268.

Raworth, K. (2012) 'A Safe and Just Space for Humanity: Can We Live Within the Doughnut?', Oxfam Policy and Practice: Climate Change and Resilience 8(1): 126.

Röckstrom, J., W. Steffen, K. Noone, A. Persson, F.S. Chapin III, E.F. Lambin, T.M. 
Lenton, M. Scheffer, C. Folke, H.J. Schellnhuber, B. Nykvist, C.A. de Wit, T. Hughes, S. van der Leeuq, H. Rodhe, S. Sörlin, P.K. Snyder, R. Costanza, U. Svedin, M. Falkenmark, L. Karlberg, R.W. Corell, V.J. Fabry, J. Hansen, B. Walker, D. Liverman, K. Richardson, P. Crutzen and J.A. Foley (2009) (2009) 'A Safe Operating Space for Humanity’, Nature 461: 472-75.

Roy, E.D., A.T. Morzillo, F. Seijo, S.M.W. Reddy, J.M. Rhemtulla, J.C. Milder, T. Kuemmerle, S.L. Martin (2013) 'The elusive pursuit of interdisciplinarity at the human-environment interface', BioScience 63(9): 745-753.

Salomon, M.K. (2016) Leading the Public into Emergency Mode: The New Strategy for the Climate Movement. Brooklyn, NY: The Climate Mobilization.

Schmitz, C.L., T. Matyók, L.M. Sloan and C. James (2012) The Relationship Between Social Work and Environmental Sustainability: Implications for Interdisciplinary Practice', International Journal of Social Welfare 21(3): 278-286.

Sodhi, N.S. and P.R. Ehrlich (eds) (2010) Conservation Biology for All. Oxford, UK: Oxford University Press.

Steffen, W., P.J. Crutzen, and J.R. McNeill (2007) 'The Anthropocene: Are Humans Now Overwhelming the Great Forces of Nature? Ambio 36(8): 614-621.

Steffen, W., A. Persson, L. Deutsch, J. Zalasiewicz, M. Williams, K. Richardson, C. 
Crumley, P. Crutzen, C. Folke, L. Gordon, M. Molina, V. Ramanathan, J.

Röckstrom, M. Scheffer, H.J. Schellnhuber and U. Svedin. (2011) ‘ The Anthropocene: From Global Change to Planetary Stewardship', Ambio 40(7): 739761.

Steffen, W., K. Richardson, J. Röckstrom, S.E. Cornell, I. Fetzer, E.M. Bennett, R. Biggs, S.R. Carpenter, W. de Vries, C.A. de Wit, C. Folke, D. Gerten, J. Heinke, G.M. Mace, L.M. Persson, V. Ramanathan, B. Reyers, S. Sörlin (2015) 'Planetary Boundaries: Guiding Human Development on a Changing Planet', Science 347(6223): 1259855.

Tedeschi, P., S.M. Bexell, and J. Nesmith (2013) 'Conservation Social Work: The Interconnectedness of Biodiversity Health and Human Resilience', in M. Bekoff (ed) Ignoring Nature No More: The Case for Compassionate Conservation. Chicago, IL: University of Chicago Press, pp. 223-235.

United Nations Environment Programme (UNEP) (2010) UNEP Emerging Issues: Global Honey Bee Colony Disorder and Other Threats to Insect Pollinators. Nairobi, Kenya: United Nations Office at Nairobi (UNON). 
United Nations (UN), Department of Economic and Social Affairs, Population Division (2017) World Population Prospects: The 2017 Revision, Key Findings and Advance Tables. New York, NY: UN.

Walke, K. (2015) 'Social Work Intervention in Creating Sustainable and Safe Physical Environments for Displaced Indigenous People', American International Journal of Research in Humanities, Arts and Social Sciences 9(4): 353-363.

World Wildlife Fund (WWF) (2014) Living Planet Report 2014: Species and Spaces, People and Places. Gland, Switzerland: WWF International. WWF (2016) Living Planet Report 2016: Risk and Resilience in a New Era. Gland, Switzerland: WWF International. 


\section{Appendix 1}

Complete list of screened-in publications

Al-Makhamreh, S., H. Alnabulsi and H. Asfour (2016) 'Social Work Field Training for the Community: A Student Self-Directed Approach in the Environmental Domain', British Journal of Social Work 46(4): 855-872.

Alston, M. (2013) Environmental Social Work: Accounting for Gender in climate Disasters', Australian Social Work 66(2): 218-233.

Bay, U. (2013). 'Transition Town Initiatives Promoting Transformational Community Change in Tackling Peak Oil and Climate Change Challenges', Australian Social Work 66(2): 171-186. 
Béres, L. (2012) 'A Thin Place: Narratives of Space and Place, Celtic Spirituality and Meaning', Journal of Religion \& Spirituality in Social Work: Social Thought 31(4): 394-413.

Besthorn, F.H. (2012) 'Deep Ecology's Contributions to Social Work: A Ten-Year Retrospective', International Journal of Social Welfare 21(3): 248-259.

Besthorn, F.H. (2013) 'Vertical Farming: Social Work and Sustainable Urban Agriculture in an Age of Global Food Crises', Australian Social Work 66(2): 187-203.

Boetto, H. and J. McKinnon (2013) 'Rural Women and Climate Change: A GenderInclusive Perspective', Australian Social Work 66(2): 234-247.

Burns, D.M. (2012) Where Canadian Social Work Educators Situate the Natural Environment - An exploration. Master's Thesis, University of Calgary, Canada.

Coates, J. and M. Gray (2012) 'The Environment and Social Work: An Overview and Introduction', International Journal of Social Welfare 21(3): 230-238.

Calvo, C. (2014) Towards Sustainable Environmental Sanitation in Costa Rica. PhD Dissertation, University of Kansas, USA.

Case. R. 2013 The Moral Economy and the Social Networks of Water Activism in Guelph, Ontario PhD Dissertation, Wilfrid Laurier University, Canada.

Darby, E.T. (2011) 'The New Color is Green: Social Work Practice and Service-Learning', 
Advances in Social Work 12(1): 113-125.

Des Marais, E., S.M. Bexell and S. Bhadra (2015) 'Transcending National Boundaries Through Reflexive Development', Social Dialog 11(3): 44-45.

Des Marais, E., S.M. Bexell and S. Bhadra, S. (2016) 'Reflexive Development: A Model for Helping Social Workers Contribute to a Sustainable Global Future', Social Work Education: The International Journal 35(1): 100-112.

Dominelli, L. (2013a) 'Mind the Gap: Built Infrastructures, Sustainable Caring Relations, and Resilient Communities in Extreme Weather Events', Australian Social Work 66(2): 204-217.

Dominelli, L. (2013b) 'Environmental Justice at the Heart of Social Work Practice: Greening the Profession', International Journal of Social Welfare 22(4): 431-439.

Drolet, J. (2012). 'Climate Change, Food Security, and Sustainable Development: A study of Community-Based Responses and Adaptations in British Columbia, Canada', Community Development 43(5): 630-644.

Drolet, J. (2015) 'Editorial', International Social Work 58(3): 351-354.

Drolet, J.L. and T. Sampson (2014) 'Addressing Climate Change from a Social 
Development Approach: Small Cities and Rural Communities' Adaptation and Response to Climate Change in British Columbia, Canada', International Social Work. Epub ahead of print 8 September 2014. DOI:10.1177/0020872814539984 Dylan, A. (2010) “Three Hundred Leagues Further into the Wilderness" Conceptualizations of the Nonhuman During Wendat-French Culture Contact, 1609-49: Implications for Environmental Social Work and Social Justice. $\mathrm{PhD}$ Dissertation, University of Toronto, Canada.

Dylan, A. (2012) 'Rethinking Sustainability on Planet Earth: A Time for New Framings', Electronic Green Journal 1(34): 1-18.

Faver, C.A. (2011) 'Seeing Ourselves in All: A Spiritual Perspective on the Unity of Life', Journal of Religion \& Spirituality in Social Work: Social Thought 30(2): 113-124.

Faver, C.A. (2013) 'Environmental Beliefs and Concern About Animal Welfare: Exploring the Connections', Journal of Sociology \& Social Welfare XL(4): 149- 168.

Faver, C.A. and J.D. Muñoz (2013) 'Environmental Concern and Action: A View from the Border', Journal of Human Behavior in the Social Environment 23(3): 345-355.

Ferrari, K.D. (2013) Rural Communities: How do Individuals Perceive Change When Industry Enters the Area? PhD Dissertation, University of South Florida, USA. 
Ferreira, S.B. (2010) 'Eco-Spiritual Social Work as a Precondition for Social Development', Ethics and Social Welfare 4(1): 3-23.

Gamble, D.M. (2012) 'Well-Being in a Globalized World: Does Social Work Know How to Make It Happen?', Journal of Social Work Education 48(4): 669-689.

Gilbert, D.J. (2014) 'Social Work and Engineering Collaboration: Forging Innovative Global Community Development Education', Journal of Social Work Education 50(2): 292-304.

Gray, M. and J. Coates (2012) 'Environmental Ethics for Social Work: Social Worker's Responsibility to the Non-Human World', International Journal of Social Welfare 21(3), 239-247.

Gray, M. and J. Coates (2013) 'Changing Values and Valuing Change: Toward an Ecospiritual Perspective in Social Work', International Social Work 56(3): 356368.

Hall, N. (ed) (2012) Social Work Around the World V: Building the Global Agenda for Social Work and Social Development. Berne, Switzerland: International Federation of Social Workers.

Havig, K.H. (2010) Empowerment for Social Justice: A Grounded Theory Study of Social Work Field Instruction Strategies. PhD Dissertation, University of Missouri- 
Columbia, USA.

Heinsch, M. (2012) 'Getting Down to Earth: Finding a Place for Nature in Social Work Practice', International Journal of Social Welfare 21(3): 309-318.

Hudson, J.W. (2014) The Natural Environment in Social Work Education. PhD Dissertation, University of Kansas, USA.

IFSW, IASSW, and ICSW (2012) 'The Global Agenda for Social Work and Social Development Commitment to Action', Journal of Social Work Education 48(4): 837-843.

Jeffery, D. (2014) 'Environmentalism in Social Work: What Shall We Teach?', Journal of Women and Social Work 29(4): 492-498.

Jones, P. (2010) 'Responding to the Ecological Crisis: Transformative Pathways for Social Work', Journal of Social Work Education 46(1): 67-84.

Kaiser, M.L. (2011) 'Food Security: An Ecological-Social Analysis to Promote Social Development', Journal of Community Practice 19(1): 62-79.

Kaiser, M.L., S. Himmelheber, S. Miller and R.A. Hayward (2015) 'Cultivators of Change: Food Justice in Social Work Education. Social Work Education 34(5): 544557.

Kemp, S.P. (2011) 'Recentering Environment in Social Work practice: Necessity, 
Opportunity, Challenge', British Journal of Social Work 41(6): 1198-1210.

Kemp, S. P., and L.A. Palinkas (2015) Strengthening the Social Response to the Human Impacts of Environmental Change. Baltimore, MD: AASSW.

Ku, K.B. (2015) 'Post-Disaster Community Development in Rural Sichuan, China', Journal of Rural and Community Development 10(3): 120-130.

Lysack, M. (2012) 'Building Capacity for Environmental Engagement and Leadership: An Ecosocial Perspective', International Journal of Social Welfare 21(3): 260-269.

Maathies, A.L., A. Kattilakaski and N. Rantamaki (2011) 'Citizens' Participation and Community Orientation, Indicators of Social Sustainability of Rural Welfare Services', Nordic Social Work Research 1(2): 125-139.

Maphumulo, L.H.S. (2015) Community Development as a Strategy to Alleviate Poverty. Master's Thesis, University of Zululand, South Africa.

Mason, L.R. (2014) 'Examining Relationships Between Household Resources and Water Security in an Urban Philippine Community', Journal of the Society for Social Work and Research 5(4): 489-512.

McKinnon, J. (2013) 'The Environment: A Private Concern or a Professional Practice Issue for Australian Social Workers?', Australian Social Work 66(2): 156-170. McKinnon, J. and U. Bay (2013) 'Guest Editorial: Social Work Enabling Sustainable 
Ecological Living', Australian Social Work 66(2): 153-155.

Miller, S.E., R.A. Hayward and T.V. Shaw (2012) 'Environmental Shifts for Social Work: A Principles Approach', International Journal of Social Welfare 21(3): 270-277.

Moghisi, M. (2011) Social Work and the Environment. Master's Thesis, Carleton University, Canada.

Norton, C.L. (2012) 'Social Work and the Environment: An Ecosocial Approach', International Journal of Social Welfare 21(3): 299-308.

Pawar, M. (2013) 'Water Insecurity: A Case for Social Policy Action by Social Workers', Australian Social Work 66(2): 248-260.

Peeters, J. (2012) 'The Place of Social Work in Sustainable Development: Towards Ecosocial Practice', International Journal of Social Welfare 21(3): 287-298.

Philip, D. and M. Reisch (2015) 'Rethinking Social Work's Interpretation of 'Environmental Justice': From Local to Global', Social Work Education 34(5): 471483.

Pulla, V. (2013) 'Critical Essay: Environmentalism and Social Work', Rural Society 22(3): 263-268.

Rambaree, K. (2013) 'Social Work and Sustainable Development: Local Voices from Mauritius', Australian Social Work 66(2): 261-276. 
Shaw, T.V. (2011) 'Is Social Work a Green Profession? An Examination of Environmental Beliefs', Journal of Social Work 13(1): 3-29.

Schmitz, C.L., T. Matyók, L.M. Sloan and C. James (2012) 'The Relationship Between Social Work and Environmental Sustainability: Implications for Interdisciplinary Practice', International Journal of Social Welfare 21(3): 278-286.

Sherraden, M.S., J. Huang, J.J. Frey, J. Birkenmaier, C. Callahan, M.M. Clancy and M. Sherraden (2015) Financial Capability and Asset Building for All. Baltimore, MD: AASSW.

Stewart, S.R. (2012) The Differences in Food Security and Related Characteristics Between Rural, Low-Income Appalachian Women Who Garden for Food and Those Who Do Not. Bachelor's Thesis, Ohio University, USA.

Teixeira, S. and A. Krings (2015) 'Sustainable Social Work: An Environmental Justice Framework for Social Work Education', Social Work Education 34(5): 513-527.

Walke, K. (2015) 'Social Work Intervention in Creating Sustainable and Safe Physical Environments for Displaced Indigenous People', American International Journal of Research in Humanities, Arts and Social Sciences 9(4): 353-363.

Walther, M. (2010) Canadian Social Work at the Intersection of Feminism, Ecology and Cultural Anti-Oppression: Making Hope into Giant Rivers Flowing. Master's 
Thesis, University of Northern British Columbia, Canada.

Willett, J. L. (2015a) Experiences of Slow Violence in Poor Kenyan Communities: Micro Disasters, Formalized Aid Responses, and Community Support Through Social Networks PhD Dissertation, University of Connecticut, USA.

Willett, J. L. (2015b) 'Exploring the Intersection of Environmental Degradation and Poverty: Environmental Injustice in Nairobi, Kenya', Social Work Education 34(5): $558-572$.

Willett, J. L. (2015c) 'The Slow Violence of Climate Change in Poor Rural Kenyan Communities: Water is Life. Water is Everything', Contemporary Rural Social Work 7(1): 39-55.

Williams, J. H. (2013) 'Social Work Research: Improving the Human Condition’, Social Work Research 37(2): 83-84.

Williams, J. H. (2014) 'Community Research: A Renewed Focus to Encompass a Broader Ecology', Social Work Research 38(2): 67-68.

Williams, J. H. (2015a) 'Human Security to Promote Capacity-Building and Sustainable Livelihoods Interventions. Social Work Research 39(1): 3-6.

Williams, J. H. (2015b) 'Marshaling Social Responses to Environmental Changes', Social Work Research 39(4): 195-198. 
Wurie, A.L. (2011) Understanding and Promoting the Notion of Sustainable Development in Countries of the Developing World. Master's Thesis, The University of Texas at Arlington, USA. 